\title{
The paranoia of endless data
}

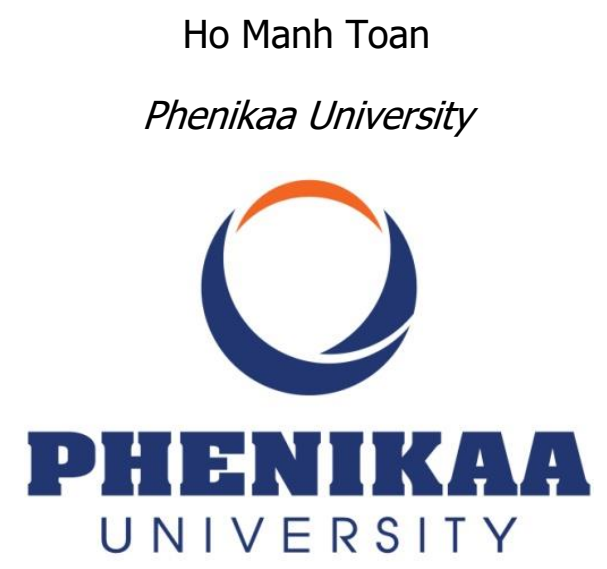

January 29, 2021

The ancient data is timeless [1], but contemporary data must be endless. Data collection occupies a large portion of research time, with collecting, then cleaning, storing, and analyzing. It would be fortunate to work on a timeless dataset, like those we used in [24], because at least there is an apparent closure to the dataset. However, as we often work with contemporary data, the process can feel a little paranoid.

The longer I work on the SSHPA database [5] or the SciMath database [6], the more I imagine Rust Cohle monologuing in my heads:

"I don't want to know anything anymore. This is a world where nothing is solved. Someone once told me, 'Time is a flat circle.' Everything we've ever done or will do, we're gonna do over and over and over again." [7]

The SSHPA database ranges from 2008 until the present [5]. Meanwhile, the range of the SciMath database dates back to 1947. Indeed, the first period of the SciMath database can be considered as historical. However, from the 2000s onward, the database's continuation means we update the data annually without an exact end.

At its worst, the endlessness can be disheartening. When you reach 1000 data points, you instantly realize there are 1000 more. When you thought you had finished 2008, a few more articles appear. The unknown number of data points also makes quality control more difficult. The first 5000 data points can be manageable, but 10000 data points make you paranoid.

If you still question that idea, try looking at Figure 1. Several best brains had to work very hard to figure out how to collect data accurately, systematically, fast, and on a lowcost basis. 


\section{Figure 1. Network data}

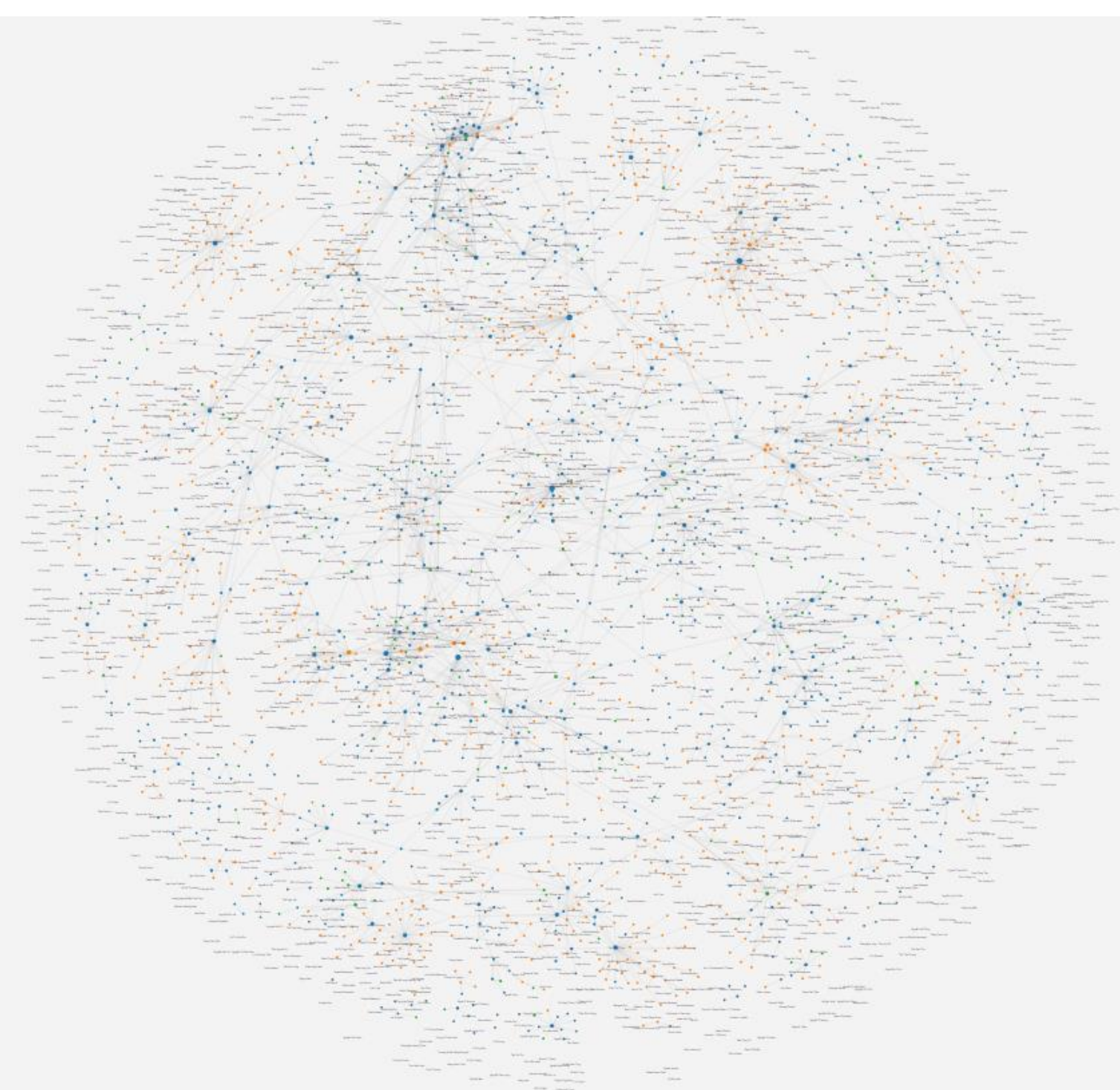

A graphical presentation of the network of Vietnamese mathematicians, extracted from the SciMath database when the total number of mathematics articles reached some 7000 [6]

On the brighter side, the endlessness of contemporary data is an excellent mental practice for research work. They offer a unique inside into the nature of science, especially social sciences. There are problems that need to be addressed. Some thoughts need to be jotted down. There are reviews that need to be rebutted. It resonates deeply with the image of Sisyphus that Albert Camus used to conceptualize the absurdity [8]. As his eternal punishment, Sisyphus had to push a rock up a mountain so it can roll back down again. He does it over and over and over again, for eternity. 
Camus suggested that: "The struggle itself towards the heights is enough to fill a man's heart. One must imagine Sisyphus happy" [8]. We must confront the endlessness, embrace it, continuously learn and unlearn, and find happiness from such a disheartening condition [9-10].

\section{References}

[1] Ho, M. T. (2021). Timeless Data. OSF Preprints, doi:10.31219/osf.io/gm98w.

[2] Vuong, Q. H., et al. (2019). Cultural evolution in Vietnam's early 20th century: a Bayesian networks analysis of Hanoi Franco-Chinese house designs. Social Sciences \& Humanities Open, 1(1), 100001,

[3] Vuong, Q. H., et al. (2020). On how religions could accidentally incite lies and violence: Folktales as a cultural transmitter. Palgrave Communications, 6, 82.

[4] Vuong, Q. H., et al. (2018). Cultural additivity: Behavioural insights from the interaction of Confucianism, Buddhism, and Taoism in folktales. Palgrave Communications, 4, 143.

[5] Vuong, Q. H., et al. (2018). An open database of productivity in Vietnam's social sciences and humanities for public use. Scientific Data, 5, 180188.

[6] Ngo, B. C., et al. (2020). The 80-year development of Vietnam mathematical research: Preliminary insights from the SciMath database on mathematicians, their works and their networks. arXiv Preprints; arXiv:2011.09328.

[7] Janning, F. (2014). True Detective: Pessimism, Buddhism or Philosophy?. Journal of Philosophy of Life, 4(4), 121-141.

[8] Camus, A. (2013). The myth of Sisyphus. Penguin UK. (Originally published in 1942)

[9] Vuong, Q. H., \& Napier, N. K. (2015). Acculturation and global mindsponge: an emerging market perspective. International Journal of Intercultural Relations, 49, 354-367.

[10] Vuong, Q. H. (2016). Global mindset as the integration of emerging socio-cultural values through mindsponge processes: A transition economy perspective. In $\mathrm{J}$. Kuada (ed.) Global Mindsets: Exploration and Perspectives (pp. 109-126). London: Routledge. 